\title{
Establishment of pericentromeric heterochromatin in development
}

\author{
Angele Santenard, Joanna Jachoviwcz, Maria-Elena Torres-Padilla* \\ From Epigenetics and Chromatin: Interactions and processes \\ Boston, MA, USA. 11-13 March 2013
}

\begin{abstract}
Mammalian development begins with fertilisation of an oocyte by the sperm, followed by epigenetic reprogramming of both parental genomes. Reprogramming involves de-novo establishment of chromatin domains, including resetting the characteristic features of pericentric heterochromatin, essential to progress through the first embryonic mitosis. We have determined the kinetics of incorporation of newly synthesised histones immediately after fertilisation. Our previous results showed that the histone variant $\mathrm{H} 3.3$ localises to paternal pericentromeric chromatin during S-phase at the time of transcription of pericentromeric repeats and that $\mathrm{H} 3.3$, and in particular its lysine 27, is required for the establishment of pericentromeric heterochromatin in the mouse embryo. Indeed, the mutation of $\mathrm{H} 3.3 \mathrm{~K} 27$, but not $\mathrm{H} 3.1 \mathrm{~K} 27$, results in aberrant accumulation of pericentromeric transcripts, HP1 mislocalisation, dysfunctional chromosome segregation and developmental arrest. We have now dissected both temporally and spatially the requirements for the establishment of pericentromeric heterochromatin after fertilisation. Our results suggest that the temporal ordered of events that follow fertilisation and the localisation of heterochromatin in the 3D nuclear space are tightly regulated and function in parallel to ensure heterochromatic silencing and subsequent development.
\end{abstract}

Published: 18 March 2013

doi:10.1186/1756-8935-6-S1-043

Cite this article as: Santenard et al: Establishment of pericentromeric

heterochromatin in development. Epigenetics \& Chromatin 2013 6(Suppl 1): O43.

IGBMÇ Strasbourg, France
Submit your next manuscript to BioMed Central and take full advantage of:

- Convenient online submission

- Thorough peer review

- No space constraints or color figure charges

- Immediate publication on acceptance

- Inclusion in PubMed, CAS, Scopus and Google Scholar

- Research which is freely available for redistribution

Submit your manuscript at www.biomedcentral.com/submit
C Biomed Central

\section{Biomed Central}

(c) 2013 Santenard et al; licensee BioMed Central Ltd. This is an Open Access article distributed under the terms of the Creative Commons Attribution License (http://creativecommons.org/licenses/by/2.0), which permits unrestricted use, distribution, and reproduction in any medium, provided the original work is properly cited. 